\title{
TRANSFORMASI Agrobakterium rhizogenese DAN INDUKSI AKAR RAMBUT PADA TANAMAN KAKAO (Theobroma cacao) UNTUK PRODUKSI SENYAWA ANTIOKSIDAN SECARA INVITRO
}

\author{
Sumaryati Syukur ${ }^{1}$ dan Zozy Aneloi $\mathbf{N}^{2}$ dan Femilya Putri ${ }^{1}$ \\ ${ }^{1}$ Laboratorium biokimia/bioteknologi Jurusan Kimia FMIPA Unand Padang \\ ${ }^{2}$ Laboratorium fisiologi tumbuhan Jurusan Biologi FMIPA Unand Padang
}

\begin{abstract}
Transformation of Ri T-DNA Plasmid Agrobacterium rhizogenese to varieties Theobroma cacao variety TSH which is growing in west Sumatra and induction of hairy roots in order to produce bioflavonoid antioxidant compounds such as, catechin, polyfenol, or monomer and oligomer flavones was successfully obtained. Three spesies of A.rhizogenese (A4,LBA 9457 and ATTCC 15834) originaly from LIPI was used to transform Ri T-DNA plasmid in MS medium via cacao embryo culture. The aim of this paper is to determine the affectivity and ability of the three species of bacterial above to produce hairy roots in cacao invitro culture. The statistical methods RAL was uses with 4 time treatments and 6 time repeated experiments. As treatment was bacterial inoculation and without inoculation as a control. The transformation result shows 2 of 3 of bacterial species have ability to induce hairy roots of.T cacao embryos counting by percentages of explants with producing hairy roots $16.66 \%$ for A4, $83.33 \%$ for LBA 9547 spesies.qualitative test of polyfenol from hairy roots transformants give $(+4)$ as compared to non transform only $(+1)$. Cathechin compound was determined by spectrophotometer as much as $0.1 \%$ for non transform and $0.87 \%$ for hairy roots transformants by LBA 9547. Conformation of plasmid Ri T-DNA hairy roots from two transformants was analysis by PCR methods. The two primers rol B1 $\left(5^{2}\right.$ ATGGATCCCAAATTGCTTCCCCCACGA3 $\left.{ }^{2}\right)$ dan rol $\mathrm{B}^{2} \quad 5^{3}$ TTAGG CTTTCATTCGGGTTTACTGCAGC $3^{3}$ ) was used. For TR-DNA the primes used is TRI $\left(5^{3}\right.$ GGAAATTGTGGCGTTGTTGTGGAC $\left.3^{\prime}\right)$ and TR2 (5' AATCGTTCAGAGAGCGTCCGA AGTT 3') . PCR analysis of DNA electrophoresis founded the band of TL region at $780 \mathrm{bp}$ and TR at $1600 \mathrm{bp}$ using DNA Ledder as DNA standard.
\end{abstract}

Keywords : transformation A.rhizogenese, PCR, Theobroma cacao, kultur embrio, kultur akar rambut, metabolit sekunder, cathechin

\section{PENDAHULUAN}

Tanaman kakao adalah tanaman yang mempunyai nilai ekonomi tinggi karena biji kakao telah terkenal dapat dibuat aneka macam pangan olahan yang disebut coklat. Dark coklat (makanan coklat yang terdiri dari $70 \%$ bubuk coklat asli) mempunyai nutrisi tinggi, karena mengandung berbagai bioaktifitas senyawa antioksidan bioflavonoid seperti, polifenol, monomer serta Oligomer ProCianidin (OPC), katekin, epikatekin, vitamin $\mathrm{C}$ yang dapat bersifat sebagai senyawa antimutagenik dan antitumor. Biji kakao juga mengandung senyawa asam lemak yang tinggi sekitar $40 \%$ diantaranya asam lemah jenuh stearat, asam lemah tak jenuh oleat dan linoleat.

Senyawa antioksidan bioflavonoid yang terdapat pada tanaman kakao $60 \%$ dari total fenolik adalah monomer flavanol yaitu katekin dan epikatekin serta oligomer prosianidin. Senyawa-senyawa tersebut dilaporkan mempunyai aktifitas antioksidan paling tinggi 
dibandingkan dengan yang berasal dari sumber tanaman lain seperti pada, strobery, bluebery, anggur dll. Senyawa senyawa tersebut sangat berpotensi untuk melawan radikal bebas, menjaga kestabilan denyut jantung, sebagai antibiotik dan antikanker didalam tubuh manusia. Senyawa bioflavonoid yang bersifat antioksidan paling tinggi yaitu $60 \%$ dari total polifenol pada tanaman kakao adalah senyawa polifenol katekin, epikatekin dan prosianidin ${ }^{[1]}$.

Penelitian ini mempunyai prospek kedepan untuk produksi senyawa antioksidan turunan bioflavonoid katekin, epikatekin dan OPC secara in vitro dengan memanfaatkan transformasi T-DNA plasmid Ri A. rhizogenes untuk membentuk akar rambut. Seleksi galur $A$. rhizogenes untuk menginduksi akar rambut, menjadi tujuan utama dan komposisi medium tumbuh untuk tujuan meningkatkan pertumbuhan kultur dan produksi katekin juga menjadi perhatian berikutnya. Penelitian transformasi plasmid $\mathrm{Ri}$ T-DNA melalui A.rhizogenese belum pernah dilaporkan di jurnal nasional maupun internasional. Prospek lain dari keberhasilan teknik transformasi ini sudah dapat memproduksi senyawa antioksidan lain melalui pembentukan akar rambut yang dapat bermanfaat untuk kesehatan dan belum banyak diteliti.

Sugawa mengemukakan bahwa kultur akar rambut sebagai salah satu bentuk dari teknik kultur jaringan merupakan hasil transformasi secara genetik menggunakan Agrobacterium rhizogenes ${ }^{[2]}$. Kultur akar rambut memberikan banyak keuntungan, antara lain pertumbuhan jauh lebih cepat dibandingkan akar normal dan memiliki kestabilan genetik dan biokimia, serta mampu mengekspresikan pembentukan produk metabolit secara stabil sepanjang periode kultur. Toivonen L. melaporkan pada beberapa tanaman, produksi metabolit sekunder dilaporkan lebih tinggi pada akar rambut dibandingkan dengan akar dari tanaman normal atau yang diproduksi dari tanaman asalnya ${ }^{[3]}$. Hal ini menjadi dasar untuk mengembangkan penelitian akar rambut dari $T$. cacao yang tersebar di Sumatera Barat.

A. rhizogenes merupakan bakteri tanah yang secara alami menyebabkan penyakit berupa terbentuknya akar rambut pada berbagai tanaman. Adanya plasmid Ri (root inducing plasmid) didalam sel A. rhizogenes mengakibatkan terjadinya transformasi dengan masuknya bagian T-DNA sel bakteri ke dalam DNA sel tanaman dan menyebabkan terbentuknya akar rambut pada bagian tanaman yang diinfeksi. Hasil transformasi yang berupa akar rambut dapat ditumbuhkan secara in vitro dan dapat dipertahankan mempunyai sifat seperti tanaman induknya, walaupun sudah terbebas dari bakteri. Menurut Giri dan Narasu ada beberapa faktor yang diketahui mempengaruhi keberhasilan dan efisiensi transformasi melalui Agrobacterium antara lain adalah kondisi kultur jaringan dan kondisi kokultivasi, kesesuaian galur bakteri dengan tanaman, komposisi medium yang digunakan dan pemilihan jaringan sebagai materi awal ${ }^{[4]}$. Dari penelitian yang telah dilakukan terhadap dua jenis kina (Cinchona ledgeriana dan C. succirubra) diketahui bahwa dari 10 galur yang diuji, hanya $A$. rhizogenes galur LBA 9457 yang mampu menginduksi akar rambut kedua jenis kina.

Biji kakao kering mengandung 12-18\% senyawa fenolik dimana $60 \%$ dari total fenolik adalah monomer flavanol yaitu katekin, epikatekin dan oligomer prosianidin. Senyawasenyawa tersebut dilaporkan sangat berpotensi untuk melawan radikal bebas dan sebagai antioksidan tinggi didalam tubuh ${ }^{[5]}$. Dilaporkan juga bahwa senyawa antioksidan pada kakao dapat mencegah penyakit kardiovaskular ${ }^{[6]}$ sebagai antioksidan utama untuk kesehatan ${ }^{[7]}$, dan sumber flavonoid yang sangat baik untuk antioksidan katekin dan prosianidin adalah terbaik jika ada dalam makanan.

Katekin dan epikatekin merupakan senyawa antioksidan utama dari tanaman kakao disamping senyawa polifenol, kuersetin, dan dimer flavon lain. Sebagai antioksidan yang paling banyak digunakan adalah $(+)$ katekin atau "cyanidol-3" yang dikenal dengan prosianidin, adalah untuk pengobatan hepatitis akut maupun kronis yang disebabkan oleh virus hepatitis ${ }^{[8]}$. Dari data yang terdapat dalam Informasi Spesialite Obat (ISO) Indonesia satu produk yang juga mengandung senyawa katekin tinggi adalah tablet entrodiar untuk antidiare.

Mei dkk menginokulasikan bagian kotiledon dan hipokotil dari Alhagi pseudoalhagi dengan 
A. rhizogenes galur A4 pada medium Murashige Skoog (MS) bebas hormon dan memperlihatkan pertumbuhan sejumlah akar rambut dalam waktu 10 hari $^{[9]}$. Hasil penelitian Ermayanti dkk menggunakan A. rhizogenes galur ATCC 15834 berhasil menginduksi akar rambut dari eksplan daun Mimba (Azadirachta indica ${ }^{[10]}$. Induksi akar rambut juga telah berhasil dilakukan pada tanaman gambir dengan menggunakan $A$. rhizogenes galur A4, LBA 9457 dan ATCC 15834.

Penelitian tentang kultur akar rambut pada tanaman kakao belum ada dilaporkan, namun kultur jaringan untuk induksi pembentukan kalus secara invitro pada $T$. cacao yang berhasil mendapatkan kalus pada medium MS dengan penambahan $11 \mathrm{mM}$ IAA dan $0,47 \mathrm{mM}$ kinetin dengan menggunakan kotiledon telah dilaporkan oleh Muswita ${ }^{[11]}$, namun penelitian tentang $T$. cacao berkaitan dengan produksi metabolit sekunder katekin belum pernah dilaporkan. Oleh karena itu dirasa perlu melakukan penelitian ini karena dapat memperoleh akar rambut hasil tanaman transgenik pada tanaman kakao. Penelitian ini merupakan tahap awal dari serangkaian penelitian untuk menghasilkan teknologi kultur akar rambut pada $T$. cacao, khususnya penggunaan beberapa galur $A$. rhizogenes untuk mendapatkan galur yang terbaik pada transformasi $T$. cacao dalam upaya produksi senyawa flavonoid katekin yang masih diimpor hingga saat ini. Kultur akar rambut yang menghasilkan katekin tinggi mempunyai prospek baik untuk produksi katekin secara bioteknologi.

\section{METODOLOGI}

Penelitian ini dilakukan dengan metode Rancangan Acak Lengkap dengan 4 perlakuan dan 6 ulangan. Sebagai perlakuan adalah penggunaan beberapa galur $A$. rhizogenes yaitu: $\mathrm{A}=\operatorname{tanpa} A$. Rhizogenes,

$\mathrm{B}=A$. rhizogenes galur $\mathrm{A} 4$,

$\mathrm{C}=A$. rhizogenes galur LBA 9457 ,

$\mathrm{D}=$ A. rhizogenes galur ATCC 15834

Total unit percobaan adalah $6 \times 4=24$

\section{Prosedur}

Sterilisasi Alat
Sterilisasi dilakukan pada semua alat yang digunakan. Botol kultur direndam satu malam dengan deterjen dan dibilas sampai bersih, kemudian direndam dalam larutan 'bayclean' selama satu malam. Kemudian dibilas sampai bersih dan dikeringkan, selanjutnya dibungkus dengan plastik kaca dan disterilisasi dengan autoklaf pada temperatur $121^{\circ} \mathrm{C}$ pada tekanan 15 psi selama 20 menit. Sterilisasi yang sama juga dilakukan pada alat-alat gelas lainnya, pinset, pisau kultur dan kertas saring.

\section{Pembuatan Larutan Stok Medium MS}

Semua zat penyusun medium MS ditimbang dan dilarutkan menurut kelompoknya. Stok hara makro, hara mikro, vitamin dan KI dilarutkan dalam $250 \mathrm{~mL}$ akuades steril, stok mio-inositol dilarutkan dalam $200 \mathrm{~mL}$ akuades steril.

\section{Pembuatan Medium MS}

Medium dibuat sebanyak 1 L dengan cara memasukkan masing-masing larutan stok yang telah dibuat dengan komposisi $50 \mathrm{~mL}$ stok makro, $5 \mathrm{~mL}$ stok mikro, $5 \mathrm{~mL}$ stok vitamin, 5 $\mathrm{mL}$ stok KI, $10 \mathrm{~mL}$ myo-inositol kedalam 200 $\mathrm{mL}$ akuades steril. Larutan diaduk sampai homogen. Volume akhir dibuat menjadi $1 \mathrm{~L}$ dengan menambahkan akuades. Selanjutnya ditambahkan $30 \mathrm{~g}$ gula dan pHnya diatur menjadi 5,8-6,0 dengan menggunakan $\mathrm{pH}-$ meter. Jika pH-nya lebih tinggi, medium ditetesi dengan $\mathrm{HCl}$ 0,5 $\mathrm{N}$ sedangkan jika lebih rendah ditetesi dengan $\mathrm{NaOH} 0,5 \mathrm{~N}$. Kemudian ditambahkan pemadat media atau agar sebanyak 7 g. Setelah itu, media dimasak sampai mendidih untuk melarutkan pemadat medianya. Selanjutnya media dimasukkan kedalam botol kultur dan ditutup dengan aluminium foil, dilapisi kertas dan diikat dengan karet lalu disterilisasi menggunakan autoklaf pada suhu $121^{\circ} \mathrm{C}$, tekanan 15 psi selama 20 menit.

Prosedur pembuatan medium MS yang digunakan untuk dekontaminasi bakteri sama dengan cara pembuatan medium MS diatas, namun ditambahkan dengan ampisilin 100 $\mathrm{mg} / \mathrm{L}$ setelah medium disterilisasi. 


\section{Pembuatan Medium YMB Kultur Bakteri}

Medium YMB cair dan padat dibuat masingmasing sebanyak $500 \mathrm{~mL}$. Medium YMB cair dibuat dengan cara memasukkan satu persatu zat kecuali agar kedalam $500 \mathrm{~mL}$ akuades. Larutan diaduk sampai homogen. Kemudian $\mathrm{pH}$ diatur menjadi 7 dengan $\mathrm{pH}$ meter, media dimasak sampai mendidih.

Pembuatan medium YMB padat sama dengan medium YMB cair, perbedaannya hanya ditambahkan pemadat media atau agar sebanyak 7,5 g. Selanjutnya media dimasukkan kedalam tabung reaksi dan ditutup dengan aluminium foil kemudian dilapisi kertas dan diikat dengan karet dan disterilisasi menggunakan autoklaf pada suhu $121^{\circ} \mathrm{C}$, tekanan 15 psi selama 20 menit.

\section{Persiapan Agrobacterium rhizogenes}

A. rhizogenes galur A4, LBA 9457 dan ATCC 15834 dipelihara pada medium agar miring YMB. Untuk memperoleh kultur bakteri dilakukan dengan cara memasukkan 1 ose bakteri ke dalam medium YMB cair $(50 \mathrm{~mL})$, kemudian diinkubasi diatas mesin pengocok (shaker) dengan kecepatan 100 rpm selama 48 jam.

\section{Persiapan Eksplan Theobroma cacao}

Eksplan yang digunakan adalah embrio yang berasal dari biji buah kakao yang telah masak, dimana kulit buah telah mengalami perubahan warna sebesar $50 \%$ atau lebih. Kulit ari biji dilepaskan dan biji dipotong hingga tersisa sedikit kotiledon yang berfungsi untuk memperkecil kontak langsung antara permukaan embrio dengan larutan sterilisasi, selanjutnya direndam dalam larutan 'Bayclean' $3 \%$ selama 1 menit dan alkohol $70 \%$ selama 30 detik. Kemudian eksplan dibilas dengan akuades steril sebanyak 3 kali dan dikeringkan dengan tisu steril. Selanjutnya kotiledon eksplan dilepaskan dengan menggunakan pinset steril.

Transformasi Eksplan dengan Agrobacterium rhizogenes

Eksplan yang bebas kontaminan diletakkan dalam cawan petri, lalu ditusuk-tusuk dengan pisau steril. Selanjutnya direndam dalam suspensi bakteri selama 30 menit. Setelah direndam eksplan dikeringkan kertas saring untuk menghilangkan sisa bakteri dan ditanam pada medium MS. Kemudian eksplan dikultur dalam ruang kultur. Ko-kultivasi dilakukan selama 1 minggu. Untuk dekontaminasi bakteri dilakukan subkultur pada medium MS yang ditambahkan ampisilin $100 \mathrm{mg} / \mathrm{L}$. Subkultur dilakukan kurang lebih sebanyak 3 kali sampai bebas bakteri yang ditandai dengan tidak terdapatnya koloni bakteri ${ }^{[9]}$. Selanjutnya eksplan ditanam kembali pada media padat tanpa ampisilin.

\section{Isolasi DNA Plasmid Ri Agrobakterium rhizogenese}

Isolasi DNA plasmid dilakukan dengan menggunakan modifikasi. Satu mata isolat $A$. rhizogenes galur LBA 9457 yang sudah dimurnikan, dimasukkan ke dalam erlenmeyer yang berisi $50 \mathrm{~mL}$ medium YMB dan diletakkan pada inkubator bergoyang dengan kecepatan $100 \mathrm{rpm}$ selama 48 jam. Kultur dituang ke dalam tabung eppendorf $2 \mathrm{~mL}$ dan disentrifugasi dengan kecepatan $10.000 \mathrm{rpm}$ selama 2 menit sehingga terbentuk pelet. Selanjutnya pelet tersebut dilarutkan dengan $500 \mathrm{uL}$ buffer TELT, ditambah dengan $50 \mathrm{uL}$, lisozim $10 \mathrm{mg} / \mathrm{mL}$. Campuran dikocok selama 5 menit dan diinkubasikan pada suhu $37^{\circ} \mathrm{C}$ selama 1 jam. Selanjutnya campuran ditempatkan di waterbath selama 1-2 menit. Setelah itu dimasukkan ke dalam air es beberapa saat. Campuran ditambah dengan 50 uL SDS 10\% dan dibolak balik sampai lisis dan terlihat berlendir. Kemudian disentrifugasi dengan kecepatan 5000 rpm selama 30 menit. Supernatan dipipet kedalam tabung eppendorf yang baru, ditambah 2-3 kali volume etanol absolut dingin dan 0,1 volume $\mathrm{Na}$-asetat dan dikocok pelan. Disentrifugasi dengan kecepatan $5000 \mathrm{rpm}$ selama 30 menit. Supernatan dibuang dan pelet dicuci dengan alkohol 70\% lalu keringkan. Pelet dilarutkan dengan akuabides steril, disentrifugasi pada $5000 \mathrm{rpm}$ selama 5 menit. Supernatan dipipet kedalam tabung eppendorf yang baru dan ditambah 2-3 kali volume etanol absolut dingin dan 0,1 volume Na-asetat $3 \mathrm{M}$. Supernatan kemudian disimpan pada suhu $-20^{\circ} \mathrm{C}$ selama 30 menit. Selanjutnya campuran disentrifugasi dengan kecepatan 10.000 rpm selama 30 menit. Pelet dicuci denga alkohol $70 \%$ dan 
dikeringkan, lalu dilarutkan dengan akuabides dan ditambah $10 \mathrm{uL}$ Rnase $10 \mathrm{mg} / \mathrm{mL}$. Campuran dihomogenkan, selanjutnya diinkubasi pada $37^{\circ} \mathrm{C}$ selama 1 jam. Setelah itu ditambah 0,1 kali volume Na-aseat dan 2,5 kali volume etanol absolut. Campuran dihomogenkan dan disimpan pada $-20^{\circ} \mathrm{C}$ selama 30 menit, lalu disentrifugasi dengan kecepatan 8000 rpm selama 5 menit.

Supernatan dibuang dan pelet dicuci dengan alkohol 70\% lalu dikeringkan. Pelet dilarutkan dengan akuabides steril dan disimpan pada suhu $-20^{\circ} \mathrm{C}$. Pelet dikeringkan dan dilarutkan dalam buffer TE PH 8,0, siap untuk diuji dengan PCR.

\section{Isolasi DNA Tanaman dan Akar Rambut Kakao}

Isolasi DNA tanaman dan akar rambut kakao dilakukan dengan menggunakan modifikasi metode Orozco-Castillo dkk ${ }^{[12]}$. Sebanyak 0,2 - 0,3 g sampel dimasukkan kedalam mortar dingin, kemudian ditambahkan 0,1 g PVPP dan nitrogen cair, lalu digerus sampai berupa serbuk halus. Selanjutnya serbuk halus tersebut dimasukkan kedalam tabung eppendorf yang berisi $1 \mathrm{~mL}$ buffer ekstrasi dengan penambahan $10 \mathrm{uL}$ mercapto etanol $1 \%$ yang sebelumnya telah diinkubasikan pada suhu $65^{\circ} \mathrm{C}$ selama 30 menit. Campuran divorteks selama 5 menit dan diinkubasikan pada suhu $65^{\circ} \mathrm{C}$ selama 30 menit. Kemudian campuran didinginkan pada suhu kamar selama 5 menit. Untuk mendegradasi protein, kedalam campuran ditambahkan $1 \mathrm{~mL}$ larutan kloroform : isoamil alkohol $\mathrm{v}: \mathrm{v}=24: 1$ dan dikocok dengan vorteks seama 5 menit, diikuti dengan sentrifugasi dengan kecepatan 11.000 rpm selama 10 menit. Dari hasil sentrifugasi cairan bagian atas dipipet dan dimasukkan ke dalam tabung eppendorf yang lain dan diekstrak kembali dengan $1 \mathrm{~mL}$ larutan klroform : isoamil alkohol $\mathrm{v}: \mathrm{v}=24: 1$ diikuti dengan sentrifugasi dengan kecepatan 11.000 rpm selama 10 menit. Cairan bagian atas dipipet ke dalam tabung lain dan ditambah dengan $5 \mathrm{~mL}$ isopropanol dingin. Campuran dikocok perlahan-lahan hingga homogen dab disimpan dalam lemari es pada suhu $4^{\circ} \mathrm{C}$ selama 30 menit. Kemudian disentrifugasi selama 10 menit dengan kecepatan $11.000 \mathrm{rpm}$. Cairan hasil sentrifugasi dibuang dan pelet
DNA dikeringkan dengan cara membalikkan tabung. Pelet DNA dilarutkan dalam $1 \mathrm{~mL}$ larutan buffer TE, ditambah $10 \mathrm{uL}$ Rnase 10 $\mathrm{mg} / \mathrm{mL}$, lalu diinkubasi pada suhu $37^{\circ} \mathrm{C}$ sekama $1 \mathrm{jam}$. Selanjutnya campuran ditambah Na-asetat $3 \mathrm{M}$ pH 5,2 sebanyak 1/10 volume, lalu dikocok hingga homogen. Campuran disentrifugasi selama 10 menit dengan kecepatan $14.000 \mathrm{rpm}$. Dari hasil sentrifugasi, cairan dibuang dan pelet DNA dicuci dengan alkohol $70 \%$ kemudian dikeringkan. Pelet DNA yang sudah kering dilarutkan dalam 500 uL buffer TE dan siap untuk diuji dengan PCR.

\section{Penetapan kuantitas dan kualitas DNA}

Penetapan kuantitas (konsentrasi) dan kualitas DNA dilakukan dengan cara elektroforesis menurut Sambrook $\mathrm{dkk}^{[13]}$. Uji kualitas dan kuantitas DNA dilakukan dengan menggunakan larutan DNA contoh sebanyak 4 $\mu \mathrm{L}$, kemudian kedalamnya ditambah $8 \mu \mathrm{L}$ akuades dan $2 \mu \mathrm{L}$ loading buffer. Kuantitas dan kualitas DNA dapat ditentukan dengan cara elektroforesis menggunakan gel agarose $1 \%(\mathrm{~b} / \mathrm{v})$

Pembuatan gel agarose dilakukan dengan melarutkan $0,3 \mathrm{~g}$ bubuk agarose dalam $30 \mathrm{~mL}$ larutan Tris-Asetat EDTA (TAE) $1 \mathrm{x}$, dan dipanaskan dalam microwave selama 1 menit. Selanjutnya gel yang sudah larut didinginkan pada suhu $65^{\circ} \mathrm{C}$ selama 30 menit dan kedalamnya ditambahkan pewarna DNA yaitu 1,5 $\mu \mathrm{L}$ etidium bromida. Campuran dikocok secara perlahan sehingga merata dan dituangkan ke dalam cetakan elektroforesis. Sisir pembuat sumur diletakkan dengan jarak $0,5 \mathrm{~mm}-1 \mathrm{~mm}$ dari dasar cetakan. Selanjutnya dibiarkan selama kurang lebih 1 jam sampai gel agarose padat. Gel kemudian diletakkan kedalam chamber elektroforesis yang telah berisi larutan TAE 1x sampai gel terendam. Contoh DNA yang telah disiapkan dimasukkan ke dalam masing-masing sumur gel.

Elektroforesis dijalankan pada tegangan 50 volt selama kurang lebih 1 jam 20 diamati di bawah UV transluminator. Konsentrasi DNA ditetapkan berdasarkan ketebalan pita standar DNA lambda yang sudah diketahui konsentrasinya yaitu sebanyak $500 \mathrm{ng} / \mu \mathrm{L}$. Kualitas DNA yang baik ditunjukkan dari hasil 
elektroforesis DNA berupa garis putih tebal yang tampak berada pada dasar sumur di bawah UV transluminator.

\section{Penentuan kandungan katekin}

Larutan standar katekin dibuat dengan cara melarutkan $5 \mathrm{mg}$ katekin dengan etil asetat p.a dalam labu ukur $25 \mathrm{~mL}$ (200 ppm), lalu dibiarkan \pm 1 jam sampai larut sempurna. Beberapa deretan larutan standar katekin dengan konsentrasi $0,5,10,15,20$ dan 25 ppm kemudian dibuat dalam labu $50 \mathrm{~mL}$. Pengukuran larutan standar katekin dilakukan dengan menggunakan spektrofotometer.

Sampel akar rambut hasil transformasi sebanyak $100 \mathrm{mg}$ dipotong kecil-kecil, kemudian dimaserasi dengan metanol. Selanjutnya disaring dan difraksinasi dengan heksan (1:1). Fraksi heksan dipisahkan dan dilanjutkan dengan fraksinasi menggunakan etil asetat (1:1). Fraksi etil asetat diambil lalu diukur absorbannya pada panjang gelombang maksimum.

\section{Uji konfirmasi T-DNA dengan PCR}

Hasil isolasi DNA plasmid, tanaman dan akar rambut kakao dianalisis dengan PCR menggunakan modifikasi metode Aoki dkk ${ }^{[14]}$. DNA Plasmid A.rhicogenes, DNA tanaman dan akar rambut kakao ditambah dengan pereaksi PCR. Pereaksi PCR berupa buffer tris-HCl $1 \mathrm{mM}$, dNTP $0,2 \mathrm{mM}$ mix yang telah berisi $\mathrm{MgCI}_{2} 25 \mathrm{mM}$, primer TL dan TR 10 pmol dan 1 unit enzim Taq DNA polymerase. Jumlah reaksi PCR adalah $25 \mu \mathrm{L}$ dengan penambahan $50 \mathrm{ng}$ DNA dan $\mathrm{H}_{2} \mathrm{O}$. ditambahkan $23 \mu \mathrm{L}$ mineral oil, selanjutnya tabung dimasukkan kedalam blokmesin PCR
Semua campuran dimasukkan kedalam tabung

(Thermolyne Amplitron 1) yang di program 1 siklus dengan profil denaturasi pada suhu $94^{\circ} \mathrm{C}$ selama 1 menit, annealing pada suhu $55^{\circ} \mathrm{C}$, selama 1 menit dan polimerase pada suhu $72^{\circ} \mathrm{C}$ selama 2,5 menit. Seluruh reaksi terdiri dari 35 siklus siklus reaksi. Kedalam tabung berisi DNA hasil amplifikasi ditambah $5 \mu \mathrm{L}$ loading buffer dan difraksinasi dengan elektroforesis $0,8 \%$ gel agarose yang mengandung $2,5 \mu \mathrm{L}$ etidium bromida $1 \%$ didalam bak elektroforesis yang berisi $1 \mathrm{x}$ buffer TAE dengan kondisi arus $36 \mathrm{~mA}$ dan 50 volt selama kurang lebih 1 jam. Sebagai marker digunakan DNA kb Ladder. Gel hasil elektroforesis divisualisasikan di atas UV transluminator dan untuk dokumentasikan dilakukan pemotretan dengan menggunakan film Polaroid 665.

\section{Pengamatan}

Pengamatan dilakukan mulai dari Hari Setelah Inokulasi (HSI) selama 3 minggu. Pada percobaan ini parameter-parameter yang diamati adalah (a) Waktu inisiasi akar rambut : pengamatan dilakukan terhadap waktu munculnya akar rambut dimulai dari hari setelah inokulasi (HSI) selama 3 minggu, (b) Respon pertumbuhan, yaitu:

1. Persentase munculnya akar rambut

Pengamatan dilakukan setelah eksplan berumur 3 minggu HSI. Persentase eksplan yang membentuk akar rambut dihitung dengan menggunakan rumus (1).

2. Persentase eksplan yang hidup

Pengamatan dilakukan setelah eksplan berumur 3 minggu HSI dengan kriteria eksplan yang hidup tidak mengalami kecoklatan dan tidak terkontaminasi dihitung dengan menggunakan rumus (2).

3. Rata-rata jumlah akar rambut

Penghitungan dilakukan pada akhir pengamatan yakni 3 minggu HSI dengan menggunakan rumus (3).

Jumlah eksplan yang membentuk akar rambut x $100 \%$

Jumlah ulangan

Jumlah eksplan yang hidup x 100\%

Jumlah ulangan

Jumlah akar yang terbentuk Jumlah ulangan

Analisis Data

Data hasil penelitian yaitu: waktu inisiasi akar rambut, persentase munculnya akar rambut, persentase eksplan yang hidup, rata-rata 
jumlah akar rambut dianalisis dengan metoda Rancangan Acak Lengkap (RAL), dan analisis kuantitatif katekin dengan metoda spektrofotometri. Hasil konfirmasi Ri-T-DNA transforman akar rambut dengan PCR disajikan secara lengkap.

\section{HASIL DAN DISKUSI}

\section{Waktu Inisiasi Akar Rambut Theobroma cacao yang ditransformasi dengan Beberapa Galur Agrobacterium rhizogenes}

Waktu inisiasi akar rambut $T$. cacao yang ditransformasi dengan beberapa galur $A$. rhizogenes disajikan pada Tabel 1. Dari Tabel 1 dapat dilihat bahwa tidak semua galur $A$. rhizogenes dapat menginduksi terbentuknya akar rambut $T$. cacao.

Perlakuan kontrol atau tanpa inokulasi dengan A. rhizogenes tidak memperlihatkan pemunculan akar rambut. Hasil yang sama juga dapat dilihat pada inokulasi dengan galur ATCC 15834. Hal ini disebabkan karena tidak terjadinya transfer T-DNA bakteri kedalam genom tanaman sehingga tidak terjadi pembentukan akar rambut.

Hal ini disebabkan oleh ketidaksesuaian galur A. rhizogenes dengan eksplan kakao. Winans ${ }^{[15]}$ mengatakan bahwa keberhasilan proses transfer T-DNA tergantung dari kecocokan/kompatibilitas antara receptor tanaman dengan isolat Agrobacterium yang digunakan. Kompatibilitas ini ditunjukkan dengan kemampuan Agrobacterium untuk menerima isyarat dari tanaman peka yang luka dan diikuti dengan terinduksinya faktor virulensi yang diperlukan dalam proses transfer T-DNA.

Kemampuan inokulasi Agrobacterium terhadap tanaman berbeda-beda dalam efektivitas transfer T-DNAnya. Hal ini berhubungan dengan virulensi isolat Agrobacterium yang dipakai dan kerentanan kultivar tanaman. Sedangkan inokulasi dengan A. rhizogenes galur A4 dan LBA 9457 memperlihatkan pemunculan akar rambut karena masuknya bagian T-DNA dari $A$. rhizogenes ke dalam genom tanaman $T$. cacao.

Hasil penelitian Noli ${ }^{[16]}$ bahwa dari 9 galur $A$. rhizogenes yang diujicobakan terhadap dua jenis kina yaitu Cinchona ledgeriana dan $C$. succirubra (Rubiaceae), hanya satu galur yaitu galur LBA 9457 yang memperlihatkan respon dalam membentuk akar rambut. Ini dapat disebabkan karena adanya perbedaan kemampuan Agrobacterium untuk dapat menginduksi akar rambut.

Hasil penelitian Giri dkk ${ }^{[4]}$, dari 6 galur $A$. rhizogenes yaitu A4, ATCC 15834, $\mathrm{K}_{599}$, LBA 9402, 9365, dan 9340, ternyata 5 galur terbukti dapat menginduksi akar rambut Artemisia anua. Hanya galur $\mathrm{K}_{599}$ yang tidak memperlihatkan respon pertumbuhan akar rambut. Hal ini disebabkan oleh perbedaan kemampuan dari Agrobacterium untuk dapat menginduksi akar rambut.

Dari Tabel 1 dapat dilihat bahwa waktu inisiasi akar rambut yang tercepat terjadi pada perlakuan inokulasi dengan galur LBA 9457 yaitu 10 HSI. Berbeda dengan hasil penelitian yang dilakukan Sukma dkk ${ }^{[17]}$ terhadap Paria Belut (T. cucumerina), dimana akar rambut mulai berkembang pada jaringan kalus hasil transformasi pada 14 HSI yang diinfeksi dengan $A$. rhizogenes galur LBA 9457.

Adanya perbedaan waktu inisiasi akar rambut $T$. cacao pada masing-masing galur $A$. rhizogenes disebabkan karena perbedaan gen pada plasmid Ri yang masuk ke kromosom tanaman T. cacao. Perbedaan kemampuan Agrobacterium untuk menginduksi akar rambut juga ditemukan dari empat galur $A$. rhizogenes yang diinokulasikan pada Brassica napus, yaitu galur ATCC 8196, ATCC 5835, A4RS dan LBA 9402, ternyata tidak ada akar rambut yang terbentuk dengan menggunakan $A$. rhizogenes galur ATCC 8196. Sedangkan galur ATCC 5835, A4RS dan LBA 9402 dapat dengan sukses menghasilkan akar rambut dengan frekuensi transformasi yang berbeda ${ }^{[18]}$.

Tabel 1. Waktu Inisiasi Akar Rambut T. cacao yang ditransformasi dengan Beberapa Galur A. rhizogenes (HSI) 


\begin{tabular}{|c|c|c|c|c|c|c|c|}
\hline \multirow{3}{*}{$\begin{array}{l}\text { Galur } \\
\text { A. rhizogenes }\end{array}$} & \multicolumn{6}{|c|}{ Waktu inisiasi (HSI) } & \multirow{3}{*}{$\begin{array}{l}\text { Munculnya akar } \\
\text { rambut (hari) }\end{array}$} \\
\hline & \multicolumn{5}{|c|}{ Ulangan } & & \\
\hline & 1 & 2 & 3 & 4 & 5 & 6 & \\
\hline Kontrol & 0 & 0 & 0 & 0 & 0 & 0 & 0 \\
\hline A4 & 0 & 0 & 0 & 0 & 14 & 0 & 14 \\
\hline LBA 9457 & 15 & 10 & 11 & 0 & 10 & 16 & $10-16$ \\
\hline ATCC 15834 & 0 & 0 & 0 & 0 & 0 & 0 & 0 \\
\hline
\end{tabular}

Keterangan $:$ HSI $=$ Hari Setelah Inokulasi

Penelitian yang dilakukan oleh Sumaryati ${ }^{[19]}$ terhadap Uncaria gambir dengan menggunakan $A$. rhizogenes galur A4, LBA 9457, dan ATCC 15834 memperlihatkan bahwa pemunculan akar rambut tercepat terjadi pada hasil transformasi dengan $A$. rhizogenes galur LBA 9457 yaitu pada 5 HSI.

Pada pengamatan yang telah dilakukan inokulasi dengan $A$. rhizogenes galur A4 memperlihatkan pemunculan akar rambut yang terjadi pada hari ke 15 HSI. Berbeda dengan hasil penelitian yang telah dilakukan Mei dkk ${ }^{[9]}$ pada tanaman Alhagi pseudoalhagi, setelah diinokulasi bagian kotiledon dan hypokotiledon dengan A. rhizogenes galur A4, akar rambut muncul dalam waktu 10 hari setelah diinfeksi.

Bajaj dan Ishimaru menjelaskan bahwa keberhasilan dalam membentuk akar rambut dari eksplan yang diinokulasi merupakan suatu indikasi terjadinya proses transfer T-DNA yang berasal dari plasmid $\mathrm{Ri} A$. rhizogenes pada genom sel tanaman $T$. cacao. Pada prinsipnya infeksi tanaman oleh $A$. rhizogenes menyebabkan masuknya satu atau kedua bagian dari transfer DNA (TL dan TR) yang terkandung dalam plasmid bakteri dan berintegrasi ke dalam genom tanaman ${ }^{[20]}$.

Integrasi DNA plasmid Ri ke dalam genom sel tanaman menyebabkan berkembangnya akar adventif. Proses pembentukan akar rambut terjadi karena T-DNA membawa gen-gen rol yang penting untuk menginduksi akar rambut. Di dalam T-DNA juga terdapat berbagai gen penyandi protein yang berperan dalam proses biosintesis zat pengatur tumbuh yaitu auksin dan sitokinin di dalam sel tanaman.

Ekspresi dari gen-gen ini membuat terjadinya perimbangan baru dari zat pengatur tumbuh internal yang akhirnya menyebabkan terjadinya induksi akar rambut. Eksplan yang tidak membentuk akar rambut setelah diinokulasi disebabkan tidak terintegrasinya $\mathrm{T}$ DNA pada sel tersebut.

\section{Respon Pertumbuhan Theobroma cacao yang ditransformasi dengan Beberapa Galur Agrobacterium rhizogenes}

Respon awal dari eksplan $T$. cacao yang diinokulasi dengan $A$. rhizogenes adalah terbentuknya akar rambut dan eksplan yang tidak membentuk akar rambut sebagian akan mati (Gambar 1). Dari gambar dapat dilihat bahwa pertumbuhan akar rambut $T$. cacao hasil transformasi masing-masing galur Agrobacterium sangat berbeda terutama dalam jumlah akar rambut yang muncul.

Hasil inokulasi eksplan menunjukkan bahwa hanya galur LBA 9457 yang mampu menginduksi pembentukan akar rambut lebih dari $50 \%$ dari total pengulangan. Keberhasilan dalam membentuk akar rambut dari eksplan yang diinokulasi merupakan suatu indikasi terjadinya proses transfer T-DNA yang berasal dari plasmid Ri A. rhizogenes pada genom sel embrio kakao.

Kompetensi eksplan ditentukan oleh beberapa faktor, antara lain spesies atau genotip asal eksplan, jenis organ yang digunakan sebagai eksplan, tingkat perkembangan organ, bahkan historis dari masing-masing eksplan yang digunakan. Respon pertumbuhan $T$. cacao yang ditransformasi dengan beberapa galur $A$. rhizogenes yaitu munculnya akar rambut, eksplan yang hidup, dan rata-rata jumlah akar yang muncul disajikan pada Tabel 2.

Dari Tabel 2 dapat dilihat bahwa tanaman $T$. cacao ini peka terhadap infeksi A. rhizogenes. Dari ketiga galur yang digunakan menunjukkan respon yang berbeda terhadap infeksi $A$. rhizogenes. Untuk persentase 
munculnya akar rambut tertinggi diperoleh pada perlakuan inokulasi dengan $A$. rhizogenes galur LBA 9457 yaitu sebesar 83,33\%, berbeda dengan perlakuan dengan kontrol yaitu sebesar $0 \%$, perlakuan inokulasi dengan galur $\mathrm{A} 4$ sebesar 16,66\%, dan ATCC 15834 sebesar 0\%.

Akar rambut yang terbentuk dari eksplan $T$. cacao pertumbuhannya sangat berbeda baik
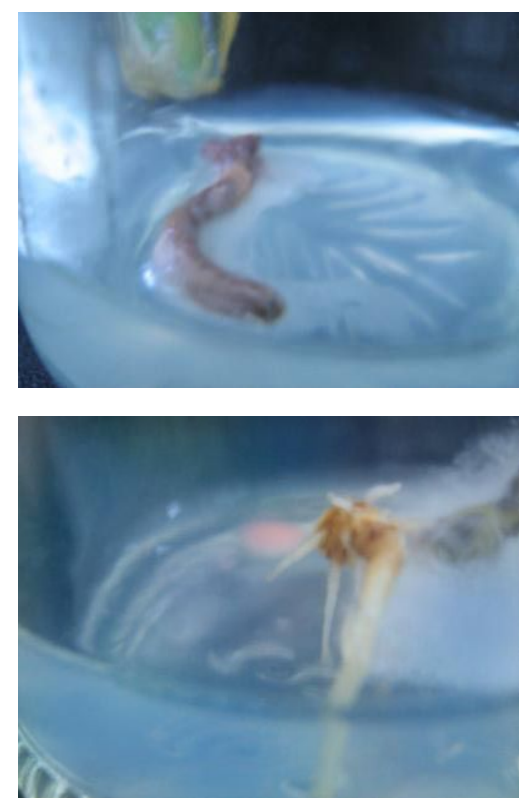

dalam jumlah akar maupun persentase munculnya akar rambut pada masing-masing galur yang diujikan. Tabel 2 memperlihatkan bahwa inokulasi dengan galur yang berbeda akan memperlihatkan respon pemunculan akar rambut yang berbeda. Hal yang sama juga ditemui pada persentase eksplan yang hidup.

Dimana perlakuan dengan LBA 9457 memperlihatkan persentase hidup tertinggi.
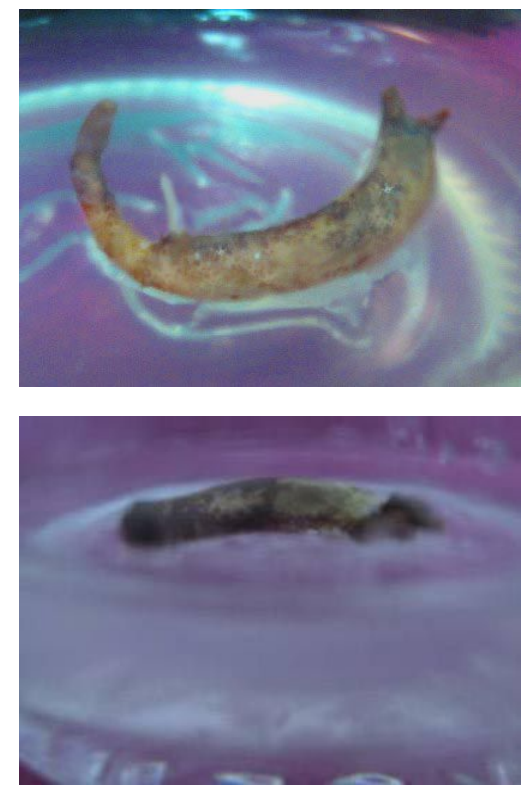

Gambar 1. Respon T. cacao yang diinokulasikan dengan beberapa galur A. rhizogenes

\section{Keterangan :}

$\longrightarrow=$ akar rambut

(a) Eksplan tanpa inokulasi bakteri

(b) Akar rambut T. cacao yang diinduksi dengan galur A4.

(c) Akar rambut $T$. cacao yang diinduksi dengan galur LBA 9457.

(d) Eksplan yang diinduksi dengan galur ATCC 15834.

Tabel 2. Respon pertumbuhan T. cacao Hasil Transformasi dengan Beberapa Galur $A$. rhizogenes

\begin{tabular}{cccc}
\hline Galur & \multicolumn{3}{c}{ Respon Pertumbuhan } \\
\cline { 2 - 4 } A. rhizogenes & $\begin{array}{c}\text { Persentase } \\
\text { muncul akar rambut } \\
(\%)\end{array}$ & $\begin{array}{c}\text { Persentase } \\
\text { eksplan yang hidup }\end{array}$ & $\begin{array}{c}\text { Rata-rata } \\
\text { jumlah akar } \\
\text { rambut }\end{array}$ \\
\hline Kontrol & 0 & $1 \%)$ & 0 \\
A4 & 16,66 & 66,66 & 1 \\
LBA 9457 & 83,33 & 83,33 & 5 \\
ATCC 15834 & 0 & 0 & 0 \\
\hline
\end{tabular}

Hasil penelitian yang dilakukan Herlina terhadap tanaman nilam (Pogestemon cablin), persentase pertumbuhan akar rambut dari inokulasi A. rhizogenes galur LBA 9402, LBA 9455 dan LBA 9457 yang diuji menunjukkan angka yang sama yaitu $77,78 \%{ }^{[21]}$. Demikian pula untuk persentase pertumbuhan akar rambut dan tunas yaitu sebesar $22,22 \%$. Walaupun persentase pertumbuhan sama, tetapi laju pertumbuhan akar rambut yang 
dihasilkan dari setiap galur tersebut berbeda. Berdasarkan hasil penelitian yang dilakukan Noli terhadap tanaman kina (Cinchona ledgeriana dan C. succirubra (Rubiacceae) rata-rata persentase pembentukan akar rambut hasil transformasi $A$. rhizogenes galur LBA 9457 berkisar dari $60-70 \%{ }^{[16]}$.

Hasil penelitian yang dilakukan oleh Ercan ${ }^{[22]}$ terhadap inokulasi Rubia tinctorum dari beberapa daerah di Turki dengan menggunakan beberapa galur $A$. rhizogenes dapat dilihat untuk $R$. tinctorum yang berasal dari Kenya yang diinokulasikan dengan galur ATCC 15834 persentase eksplan yang membentuk akar rambut adalah $75 \%$, inokulasi dengan galur R1000 adalah 50\%, dan inokulasi dengan galur 9356 adalah $18 \%$ sedangkan untuk inokulasi dengan galur 2628 persentase eksplan yang membentuk akar rambut adalah $23 \%$.

Dari hasil penelitian yang telah dilakukan, untuk rata-rata jumlah akar rambut yang paling tinggi dapat terlihat pada perlakuan $A$. rhizogenes galur LBA 9457 yaitu sebesar 5,4 dan diikuti dengan galur A4 dimana rata-rata jumlah akar rambut sebesar 1. Berdasarkan rata-rata jumlah akar rambut dan persentase pemunculan akar rambut maka dapat dinyatakan bahwa inokulasi dengan menggunakan galur LBA 9457 menunjukkan hasil terbaik.

Pemanfaatan kultur akar rambut untuk menghasilkan senyawa metabolit sekunder telah banyak dilakukan, antara lain lobelin dari Lobelia inflata dan katarantin dan ajmalin dari Catharantus roseus. Hasil penelitian Lodhi dan Charlwood ${ }^{[23]}$ terhadap kultur akar rambut Rubia Peregrina (Rubiaceae) hasil transformasi dengan $A$. rhizogenes galur LBA 9402, produksi anthracquinones yang dihasilkan dua kali lipat dari tanaman lapangan $\left(2,12 \pm 0,12\right.$ dan $1,23 \pm 0,12 \mathrm{mg} \mathrm{g}^{-1}$ bobot kering).

Hasil uji dari kontrol yang mati dan inokulasi dengan ATCC 15834 memberikan hasil yang sama yaitu negatif dimana hasil uji tidak memperlihatkan perubahan warna. Hal ini disebabkankan tidak tumbuhnya eksplan sehingga metabolit yang diharapkan tidak terbentuk. Hasil uji dari inokulasi dengan galur
LBA 9457 memperlihatkan intensitas warna yang lebih pekat. Banyaknya jumlah akar berkemungkinan mengandung senyawa flavonoid yang lebih tinggi sehingga meyebabkan perubahan warna yang lebih pekat. Hasil ini sesuai dengan penelitian Ermayanti yang melaporkan bahwa produksi metabolit sekunder lebih tinggi pada akar rambut dibandingkan pada tanaman normal atau yang diproduksi dari tanaman asalnya ${ }^{[10]}$.

Dari penelitian ini maka dapat dilakukan serangkaian penelitian lanjutan tentang penentuan jenis senyawa flavonoid yang dihasilkan pada tanaman $T$. cacao yang telah ditransformasi dan upaya meningkatkan produksi flavonoid dari T. cacao melalui kultur akar rambut. Akar yang muncul dikultur dalam medium cair sehingga pertumbuhannya akan semakin cepat. Namun masih ada beberapa faktor yang mempengaruhi pertumbuhan akar rambut dan produksi metabolit sekunder diantaranya kestabilan sel dan genetiknya ${ }^{[19]}$.

\section{Identifikasi Flavonoid dan Penentuan Kandungan Katekin}

Identifikasi flavonoid yang dilakukan pada tanaman T.cacao hasil transformasi dengan $A$. rhizogenes memperlihatkan kandungan flavonoid yang lebih tinggi dibandingkan tanaman non transforman/kontrol. Hal ini dapat dilihat dari warna yang muncul pada sampel setelah ditambahkan $\mathrm{HCl}$ pekat dan serbuk Mg (Gambar 2).

\section{Analisa Kuantitatif Katekin}

Penentuan kandungan katekin secara kuantitatif hasil transformasi dengan $A$. rhizogenes dilakukan dengan menggunakan spektrofotometer UV. Spektrum dari senyawa katekin memperlihatkan puncak serapan yang khas pada panjang gelombang $260-280 \mathrm{~nm}$ dan puncak serapan maksimum $(A)=0,2$ terjadi pada $\lambda 280 \mathrm{~nm}$.

Spektrum dari sampel akar rambut hasil transformasi dengan A. rhizogenes memperlihatkan puncak serapan yang muncul pada $\lambda 280 \mathrm{~nm}$ dan $A=0,16$. Kandungan katekin yang diukur pada sampel tanaman ini dibandingkan dengan kandungan katekin pada 
pengukuran absorban standar katekin. Dari harga absorban larutan standar katekin didapatkan persamaan regresi $\mathrm{Y}=0,0162 \mathrm{x}$ 0,0335 .

Dengan mensubstitusikan harga absorban sampel ke dalam persamaan di atas dapat diketahui kandungan katekin pada kontrol non transformasi dan hasil transformasi akar rambut A.rizogenese LBA 9457, masing- masing sebesar $0,196 \%$ dan $0,87 \%$. Dari hasil uji secara kuantitatif ini juga terlihat bahwa kandungan katekin pada tanaman T.cacao hasil transformasi lebih tinggi dari (4 x lipat) dibandingkan tanaman non transformasi. Kandungan transforman lain sangat kecil dibandingkan non transforman data tidak ditampilkan.

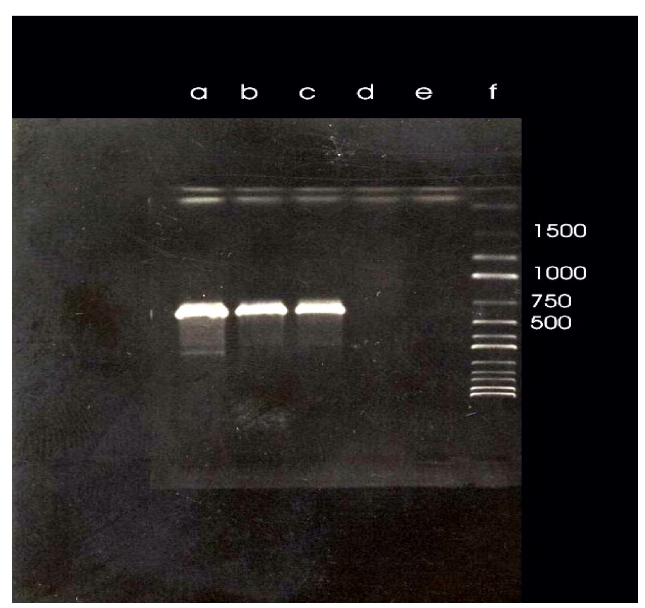

Gambar 2. Amplifikasi fragmen TL-DNA pada akar T.cacao hasil transformasi dengan A.rhizogenes galur LBA 9457.

Keterangan: (a) Plasmid A. rhizogenes (primer rol B), (b) akar rambut transforman T.cacao Trinitario (primer rol B), (c) akar rambut Transforman T.cacao Forestero (primer rol B),(d)dan (e) Non transform T.cacao (f) Marker $1 \mathrm{~kb}$ DNA Ladder

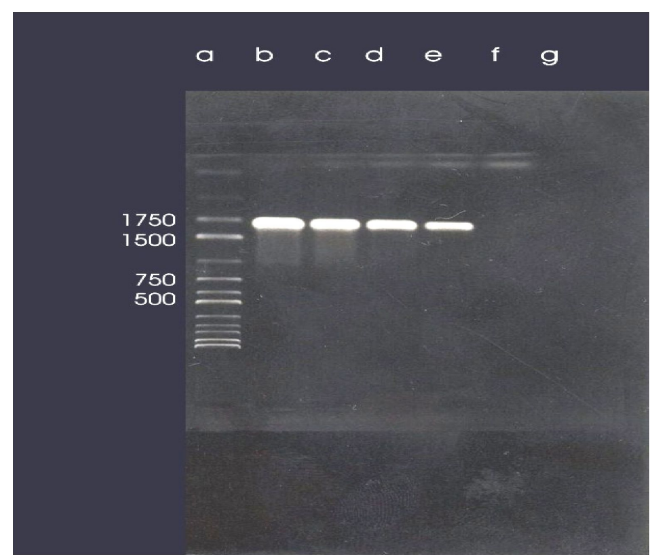

Gambar 3. Amplifikasi fragmen TR-DNA pada akar T.cacao hasil transformasi dengan A.rhizogenes LBA 9457.

Keterangan: $\quad$ (a) Marker 1 kb DNA Ladder,(b) \&(c) Plasmid A. Rhizogenes galur LBA 9457 (primer TR), (c) akar rambut T.cacao transforman Trinitario (primer TR), (d) Akar rambut T.cacao Forestero (primer TR), (e) Transforman (primer TR), (f) dan (g) Non Transform (primer TR). 
Gambar 4. Kandungan flavonoid secara kualitatif

Keterangan :

a. Sampel awal sebelum penambahan $\mathrm{HCl}$ pekat dan serbuk $\mathrm{Mg}$

b. Kandungan flavonoid non akar rambut T.cacao Non transforman/kontrol yaitu: +1 .

c. Kandungan flavonoid pada akar rambut hasil Transformasi kultur in vitro yaitu :+ 4 .

\section{KESIMPULAN}

Berdasarkan penelitian tentang induksi akar rambut Theobroma cacao dengan beberapa galur Agrobacterium rhizogenes dalam upaya produksi senyawa flavonoid secara in vitro yang telah dilakukan, maka dapat disimpulkan bahwa dari ketiga galur yang telah diuji hanya dua galur $A$.rhizogenes yaitu galur A4 dan LBA 9457 yang dapat menginduksi akar rambut $T$. cacao. Persentase eksplan yang dapat membentuk akar rambut dari inokulasi galur A4 sebesar 16,66 \% dan 83,33\% dari inokulasi dengan LBA 9457. Dari hasil transformasi $T$. cacao dengan A.rhizogenese galur LBA 9457 yang mengandung senyawa katekin tertinggi sebanyak lebih dari4 kali lipat $(0,87 \%)$ dibandingkan hasil non transformasi $(0,19 \%)$.

\section{UCAPAN TERIMA KASIH}

Ucapan terimakasih ditujukan pada DP2M, Departemen Pendidikan Nasional Proyek Penelitian Fundamental tahun 2008 kontrak No:005/SP2H/PP/DP2M/III/2006.

Penghargaan yang tinggi juga diberikan pada kelompok Penelitian Bioteknologi Tanaman FMIPA-UNAND Padang, atas semua kerja sama yang baik.

\section{DAFTAR PUSTAKA}

1. Kim, H, \& Keeney, P. G. 1984. Epicatechin content in fermented and unfermented cocoa beans. Journal of Agricultural and Food Chemistry. 47. 3693-3701.

2. Sugawa. H, Kagami, dan Suzuki, 2004. High-frequency tranformation of
Lobelia erinus L. by agrobactarium rhizogenes-mediated gene tranfer. Plant cell reports 22 (10): 759-764.

3. Toivonen, L. 1993. Utilization of hairy root cultures for production of secondary metabolites. Journal of Biotechnology. Prog. 9 : 12-20.

4. Giri, A., and M. L. Narasu, 2000. Transgenic Hairy Root : Recent Trends and Aplications. Biotechnology Advances. 18: 1-22.

5. Sanbogi, C., Osakabe, N., Natsume, M., Takizawa, T., Gomi, S., \& Osawa, T. (1998). Antioxidative polyphenols isolated from Thoebroma cocoa. Journal of Agricultural and Food Chemistry, 46, 454-457.

6. Heiss C, Dejam A, Kleinbongard P,Schewe T,Sies H,Kelm M, 2003, Vascular effects of cocoa rich in flavan-3-ols.JAMA, 290:1030-1031.

7. Waterhouse AL,Shirley JR,Donovan JL, 1996, Antioxidants in chocolate[letter].Lancet, 348:834.

8. Bakhtiar, A. 2005. Potensi Senyawa Bahan Alam Flavonoid Sebagai Obat dan Kosmetik. Universitas Andalas. Padang.

9. Mei, Y. W., Wang, J.B., Luo, D., Jia, J. F. 2001. Regeneration of Plants From Callus Cultures of Roots Induced by Agrobacterium rhizogenes on Alhagipseudoalhagi.

http://gob.oupjournals.org/cgi/content/ abstracy/73/6/60.29 Mei 2005.

10. Ermayanti, T. M., L. Sari. E. M. R. Siregar \& Sudrajat. D. 2000. Transformasi Mimba (Azadirachta indica A JUSS) dengan Agrobacterium rhizogenes galur ATCC 15834. Puslitbang Bioteknologi. LIPI. 
11. Muswita. 1992. induksi kalus pada Kakao dengan Medium MS dengan Penambahan 2,4 D, IAA dan BA. Skripsi Sarjana Biologi. Universitas Andalas. Padang.

12. Orozco-Castillo, K., J. Chalmers, R. Waugh and W. Powell. 1994. Detection of Generic Diversity and Selective Gene Integration In Coffe Using RAPD Marker. Theor.Appl.Genet. 87: 934-938.

13. Sambrook, J.E., E.T. Fritsch and T. Maniatis. 1989. Molecular Cloning, A Laboratory Manual. Second Edition. Cold Spring Harbor Lab Press. New York p. 568-600.

14. Aoki, Y., H. Matsumoto, Y. Asako, Y. Matsunaga, and K. Shimomura. 1997. Variation Of Alkaloid Productivity Among Several Clones Of Hairy Roots and Generated Plants Of Atropa belladona Transformed With Agrobacterizum rhizogenes 15834. Plant Cell Reports 16: 282-286.

15. Winans.S. 1992. Two Ways Chemical Signalling Agrobactarium-plant interactions. Microbiol.rev. 56:12-31.

16. Noli, Z. A. 2004. Pertumbuhan dan Produksi Alkaloid Kinolina dari Kultur Akar Rambut Kina (Cinchona ledgeriana Moens dan C. succirubra Pavon ex Klotzsch) Hasil Transformasi Agrobacterium rhizogenes Glaur LBA 9457. Disertasi. Universitas Padjajaran. Bandung.

17. Sukmadjaja, D., dan P, Doran. 2001. Kinetik dan Karakteristik
Pertumbuhan Kultur Akar Rambut dari Beberapa Genotipe Arabidopsis thaliana. Jurnal Bioteknologi Pertanian. Vol.6.No.2.pp.67-73.

18. Sumaryati, Desrina dan N.Z. Aneloi, 2006, Induksi akar rambut tanaman Gambir (Uncaria gambir Roxb) dengan plasmid $\mathrm{Ri}$ beberapa galur Agrobakterium rhizogenese secara In vitro, Laporan Penelitian, 1-51.

19. Bajaj, Y. P. S., and K. Ishimaru. 1999. Genetic Transformation of Medicinal Plant. In Bajaj, Y. P. S (eds). Biotechnology in Agriculture and Forestry, Transfenic Medicinal Plants. Springe-verlag. Berlin. 3-7.

20. Herlina N. D., 1995. Kepekaan Nilam (Pogostemon cablin Benth) Terhadap Infeksi Agrobacterium rhizogenes. Skripsi Sarjana Biologi. IPB, Bogor

21. Ercan, G. A., Taskin M., Turgut, K. dan Yuce, S. 1999. Agrobacterium rhizogenes-Mediated Hairy Root Formation in Some Rubia tinctorum L. Populations Grown in Turkey. Research Article 23 : 373-377.

22. Lodhi, A.H. and B.V Charlwood (1996). Agrobacterium rhizogenes mediated transformation of Rubia pregrine $L$. In vitro accunulation of Anthraquionones. Plant Cell Tiss. and Org. Cult. 46: 103-108.

23. Sheng, J., and Citovsky. 1996. Agrobacterium-plant Cell DNA Tranport, have Virulence Proteins will Travel. Plant Cell: 1699-1710. 